\title{
TERVEYDEN LÄHTEILLÄ
}

Timo Joutsivuo ja Heikki Mikkeli (toim.:) Terveyden läbteillä. Länsimaisten terveyskäsitysten kulttuuribistoriaa. SHS 1995.

Jumalallisten pilven äärettömät varjot eivät enää vaella terveyden lähteen kuvastimessa, vaan lähteen heijastus, sen esittämä toinen, on ainoastaan omat maalliset ja äärelliset kasvomme, empiirisesti todennetut, kuoleman kalvamat, mutta myös äärelliseen tietoon luottavat ja terveydestä toivonsa hakevat. "Jumalten hylkäämässä maailmassa terveys korvaa pelastuksen", kuten Michel Foucault lainasi Guardia Klinikan synnyssä, yhdessä ehdottomasti loistavimmista teoksistaan. Suvereenilla tyylillään Foucault muotoili terävästi lääketieteen ja terveyden aseman modernissa maailmassa. Lääketieteen perustava paikka modernin ihmistieteiden arkkitehtuurissa johtuu sen läheisyydestä näitä kaikkia kannattelevalle antropologiselle rakenteelle. Ihmisen äärellisyydestä tulee samalla tämän positiivisen tiedon ehto. Tästä juontuu myös lääketieteen arvovalta olemassaolon konkreettisissa muodoissa. Se tarjoaa modernille, äärellisyytensä "empiirisesti" tietävälle ihmiselle tämän tinkimättömät, mutta samalla luottamukselliset äärellisyyden kasvot. Kuolema toistetaan siinä jatkuvasti, mutta siitä myös puhdistutaan, ja vaikka se jatkuvasti muistuttaa rajasta, jota ihminen kantaa mukanaan, se puhuu myös siitä teknisestä maailmasta, joka on aseistettu ja positiivinen, modernin ihmisen äärellisyyden täysi muoto. Juuri tämän takia modernissa maailmassa lääketieteen eleet, sanat ja katseet saavat aikaisemmin vain matemaattiselle ajattelulle kuuluneen filosofisen tiiviyden, ja Bichat'n, Jacksonin ja Freudin tärkeys kultuurissamme todistaa lääketieteellisen ajattelun yhdistymisestä täysin ihmisen filosofiseen asemaan.

Klinikan synty esitti lääketieteen epistemologisen murroksen yhdistäen sen modernien ihmistieteiden epistemologiaan. Teos asettui ranskalaiseen tieteenfilosofian traditioon, jossa varsinkin Georges Canguilhelmin työt ovat pohtineet lääketieteen ja biologian epistemologian historiaa. Canguilhelmin epistemologinen näkökulma muodosti kohteensa eräänlaisessa ideaalissa "tila-ajassa", joka Foucault'n sanoin ei ole annettu historioitsijan oppineisuuden kasaamassa "realistisessa" ajassa muttei myöskään tämän päivän tieteen autoritatiivisesti erikseen leikkaamassa idealisoidussa tilassa. ${ }^{1}$ Foucault, jolle terveys ja lääketieteellinen tiedonmuoto oli koko tuotantoa halkova teema, avasi tietenkin myös terveyden, hallinnan ja vallan yhteyksien tutkimuskentän ja liikkui väestöjä koskevista biovallan teemoista terveyden reflektoinnin kautta tapahtuviin itsen teknologioihin. Jos "ranskalaiset" ovat asettaneet tiedonmuotoja kysyviä ongelmia tutkien sen rationalisaation muotoja, joka kontingenssissa kehittyen asettaa universaaleja valtapyrkimyksiä, ovat englantilaiset sosiaalihistorioitsijat taas harjoittaneet pitkään sosiaalisten käytäntöjen historiaa ja tehneet enemmän terveyden sosiaalihistoriaa, joka varsinkin viime aikoina on keskittynyt Roy Porterin ympärille.
Suomessa emme juuri ole saaneet maistaa sen enempää lääketieteen kriittistä tieteenhistoriaa kuin terveyden sosiaalihistoriaakaan. Hannu Vuoren sosiaalilääketieteen historia on poikkeus, mutta lähinnä johdannoksi sopiva suhteellisen kritiikitön ja näkökulmaton anakronistisen edistyshistorian yleisesitys. Siksi Heikki Mikkelin ja Timo Joutsivuon toimittama Terveyden läbteillä on mielenkiintoinen avaus terveyden teeman historialliseen käsittelyyn. (Joitakin yrityksiä on ollut myös Suomen Lääketieteen Historian Seuran vuosikirjoissa.) Mikkeli onkin kunnostautunut aatehistoriallisten aiheiden esittelijänä, ja Terveyden lähteillä-kirjan eri artikkeleiden kirjoittajissa on poikkeuksellisen mielenkiintoisia historioitsijoita, joita lukee mielellään ja joiden käsittelemistä ajatuksista voi todella innostua ja yrittää kehitellä myös omia keloja. Pyrkimyksestä avartaa näkökulmaa kertoo myös, että mukaan on otettu väkeä sosiologiasta, valtioopista, Kristiina-instituutista ja niin edelleen. Eri tieteenalojen näkemystenvaihtohan edellyttää, ettei yhdellä ole monopolia aina viimeiseen tulkintaan.

Hieman karkeasti yleistettynä (ja lukuisat säännön vahvistavat poikkeukset lukuunottaen) voitaisiin sanoa, että kaikesta tieteenalan sisäisestä kritiikistä huolimatta historia tieteenä on ollut kuitenkin usein vähän kuin hygienia ennen Pasteuria - kaikkivoipa ja voimaton. Hygienia, joka ei osannut kohdistaa katsettaan bakteeriin, oli kiinnostunut kaikesta mahdollisesta, jokainen ilmiö oli sinällään tärkeä, 
mutta nähdessään syitä kaikkialla se ei voinut nähdä niitä samanaikaisesti yhtään missään. Historia on ollut kiinnostunut jokaisesta historiallisesta ilmiöstä ja historioitsijoille on riittänyt jokaisen vielä kuvaamattoman ilmiön kuvaus. Historiallisten "tosiasioiden" (aktualisoituneiden) vartijana se on ollut kaikkivoipa myös voidessaan hyökätä jokaista teoriaa tai vahvempaa tulkintaa vastaan "historiallisten tosiasioiden" moninaisuudella pystymättä kuitenkaan itse useinkaan tuottamaan mielenkiintoista näkökulmaa tai vertailua. Niinpä on usein tyydytty historian ilmiöiden selittämiseen pois toisilla historian ilmiöillä tai sitten näkökulmien etsiminen on korvattu vain riitelyllä lähdeviitteistä. Ja koska historiankirjoitus on harvoin ollut todella "historiallista" (mikä edellyttäisi synkronisen ja diakronisen elementin uudelleen miettimisen, jotain mitä "postmodernin" niin parjaama struktualismi osaltaan sai juuri aikaan) erotettuna historiallisuudesta sen arkipäiväisessä mielessä, ajatuksena tapahtumien lineaarisesta sarjasta, on se usein tyytynyt hyvin tavanomaisiin vakioihin, joiden ympärille historiallisia muuttujia on $\mathrm{ka}-$ sattu tyyliin "mitä enemmän sitä parempi". (Tässä myös sen inho epookki-ajattelua vastaan, joka pyrkii juuri pysäyttämään lineaarisuuden ja rakentamaan vertailun näkökulman, "historiallistamaan" historian.) Räikeimmillään tuloksena on diakroninen deskriptio annettujen vakioiden historiallisista seikkailuista, usein myös ilman sitä tekijää, jonka muiden muassa Paul Veyne näkee historian kirjoi- tuksen keskeisenä ohjenuorana, eli juonta.

Tieteiden historiankirjoitus on usein ollut tästä räikein esimerkki, ja kuten Mikkeli esipuheessa toteaa, on lääketieteen historia ollut usein emeritusprofessoreiden harrastus, samalla kun lääketieteen historian yleisesitykset ovat olleet lähinnä luetteloita mullistavista keksinnöistä, joiden perustalla biolääketiede vähitellen syntyi. Kyse on ollut eräänlaisesta edellä esitetyn epistemologisen näkökulman "vastakohdasta", jossa nykytieteen näkökulman asettamassa ideaalissa tilassa muodostettu kehityshistoria esitetään historian lineaarisessa ajassa. Vastavoimina lääketieteen historian yleisesityksille Mikkeli mainitsee sosiaalilääketieteen ja kriittisen lääketieteen historian ja mainitsee Foucault'n ja Ivan Illichin yhdessä jälkimmäisen suunnan edustajina. Haluamatta ryhtyȧ "mestarin oikein luennan" vartijaksi en voi olla puuttumatta tähän ja olla korostamatta Foucault'n eroa Illichin tapaisista holistisista helppoheikeistä. Foucault'n kysymyksenasettelu ei avaudu biolääketiede vastaan holistinen lääketiede -erolla (jako, joka hallitsee hiukan liikaa myös Mikkelin johdantoa). Tämän korostaminen on tärkeää, koska juuri anglosaksisessa vastaanotossa Foucault'n tutkimukset on usein niputettu vaihtoehtolääketieteen kanssa. Tämä väärinymmärrys juontaa juurensa siihen, että Hulluuden bistoria ilmestyi englanniksi lyhennettynä juuri antipsykiatrisen liikkeen julkaisusarjassa. Foucault'n kieltäytyminen tarjoamasta valmista teoreettista kehikkoa sille, minkä hän näki olevan ominaista poliittisille taisteluille, esti häntä kuitenkin kritisoimasta niitä käyttöjä, joihin hänen teoksensa joutuivat (tästä juontuvat myös tietyt positiiviset kommentit haastatteluissa Illichin ja Langin suuntaan). Sen sijaan tieteenhistoriassa jako biolääketiede vastaan holistinen lääketiede on kuitenkin yhtä naiivi kuin jako vaihtoehtolääketiede vastaan koululääketiede, tai irrationalismi vastaan rationalismi.

Tarkennuksena esipuheeseen tulee myös huomauttaa, ettei Foucault'n ongelma myöskään ollut kuinka ihmisen asema psykofyysisenä kokonaisuutena hämärtyi, vaan pikemminkin juuri toisin päin, eli miten tietyt hallinnan muodot pyrkivät juuri tekemään ihmisestä psykofyysisen kokonaisuuden. Foucault'n kritiikki oli juuri totalisoivia (eri asia kuin totalitaristisia) hallinnan muotoja vastaan.

Erottelullaan vain keskeisesti sairauksien parantamiseen tähtäävän ja toisaalta terveydestä huolehtivan, ennaltaehkäisevän lääketieteen välillä Mikkeli ymmärtääkseni kuitenkin haluaa korostaa kirjan keskittymistä juuri terveyden hoitamisen asemaan elämäntavan tuottajana. Mikkeli korostaa dietetiikan merkitystä antiikissa ja hygienian merkitystä renesanssissa koko elämäntavan määrittäjänä ennaltaehkäisyn mielessá. On kuitenkin paikallaan korostaa (kuten Mikkeli omassa artikkelissaan tekeekin) vanhan ennaltaehkäisevän dietetiikan ja modernien hygieenisten liikkeiden (1800-luvulla alkanut hygieniadiskurssien valtava kasvu: rotu-, sosiaali- ja moraalihygieniat ja niin edel- 
leen) ennaltaehkäisy-strategioiden eroa. Jälkimmäinen keskittyi enemmän "elämän sinänsä" ohjailuun (siinä olevien vaarojen eliminoimiseen ja sen tuottavuuden hallinnoimiseen) kuin ajatukseen elämäntavasta. Sillä oli myös aseinaan riskilaskennat ja modernit tiedonmuodot (kuten tilastotieteiden synnyn mahdollistama laajojen ilmöiden hallinnointi), jotka erottivat sen aikaisemmista ennaltaehkäisyn aatteista aivan kuten modernit normalisaation, tilastollisen normaalin sekä organis-

_.. min normaalitilan käsitteet ovat eri asioita kuin vanha kultaisen keskitien ajatus tai humoraalipatologinen tasapainoajattelu. Jos tätä eroa haluttaisiin korostaa, ei normaalitilaa ja tasapainotilaa kenties tulisi käyttää synonyymeinȧ, kuten jotkut kirjan artikkeleista tekevät. Strategisena korostuksena voi tietenkin valita joko menneen samankaltaisuuksien tai erojen korostamisen, mutta "jo muinaiset kreikkalaiset" -tyylissä on myös omat vaaransa, jotka tulee pitää mielessä kun huomautetaan Hippokrateen Ympäristötekijöistäteoksen moderniudesta (senkö tähden että tavat yritetän palauttaa ympäristön ja perimän vaikutukseen) tai (sinänsä aivan oikein) hippokraattisesta ajatuksesta, että pyhän taudin (kaatumataudin) syyt nähtiin täysin luonnollisina. Hippokrates kritisoi kyllä niitä, jotka erottivat tämän taudin hoidon jumalallisten puhdistumisriittien asiaksi, mutta kuten esimerkiksi Georg Vlastos on tästä yhteydestä huomauttanut: "Ollaksemme varmoja, 'luonnollinen' ei tarkoita 'sekulaaria'."2 Luonnolliset tapahtumat eivät olleet vähemmän ju- malallisia, eli kuten tutkielman kirjoittaja, joka itse asiassa puolustaa jumalia, asian ilmaisee: "Siksi tätä sairautta ei pidä erottaa joukosta ja pitää muita pyhempänä, vaan kaikkia tauteja täytyy pitäả sekä jumalallisina että inhimillisinä." Kiinnostavaa olisi antiikin naturalismin ja modernin sekularisaation luomien terveyskäsitysten vertailu kenties enemmän näiden erojen etsimisen kautta ja varoen lipsahtamasta "täällä taas universaali rationalismi näyttäytyi taikauskoa vastaan" -kehikkoon. Se, mikä monissa artikkeleissa hieman pistää silmään, on paheksunta, kuinka lääketiede oli/on vielä kristillis-moraalista tai kuinka se "säilytti" vanhoja syntiin liittyviä merkitysyhteyksiä. Kritiikki suhteutetaan puhdasta tiedettä vielä likaavaan uskonnolliseen jäämistöon, sen sijaan että pohdittaisiin puhtaan sekularisaation ongelmia ja terveyden roolia siinä perustavana "arvon" lähteenä. (Eikö Jumala julistettu kuolleeksi jo aikoja sitten?) Rajuimmat "äärimedikalisaatio"-tendenssit modernissa ovat pyrkineet olemaan puhtaan neutraaleja, ja kylla puhdas sekulaari kustannus-hyöty-kalkyyli hallitsee nykyistä terveyspolitiikkaa "makrotasolla" huomattavasti enemmän kuin kristillinen moralismi. Ja mitä tulee "mikrotasoon", niin voi lainata Ilpo Helénin artikkelin toteamusta: "Länsimaista hyvää ja oikeaa käyttäytymistä on yhä vähemmän johdettu ja iskostettu tiukkojen kristillisten moraalikoodien perusteella, ja konkreettisia, ruumiillisia elämänkäytäntöjä koskevat ohjeet, neuvot ja suositukset ja ongelmoinnit ovat voittaneet alaa."

\section{HISTORIAN NESTEET}

Varsinaisesti kirja alkaa historioitsijoiden tasapainoiluna humoraalipatologian kanssa esittäen erittäin mielenkiintoisen johdannon antiikista lähes modernin kynnykselle ulottuvasta käsityksestä humoraalien eli ruumiin nesteiden tasapainosta terveyden takaajana. Joutsivuo esittelee antiikin terveyskäsityksiä lähinnả Galenoksesta eteenpäin sekä kristinuskon suhtautumista terveyteen, Mikkeli johdattaa meidät renessanssin terveysohjeisiin, ja Heikki Lempa miettii 1700-luvun lopun saksalaista filantropismia pyrkien suhteuttamaan sitá Eliaksen, Ostreichin ja Foucault'n laajempiin näkökulmiin.

Artikkeleiden mielenkiintoisuudesta huolimatta ei-historioitsijaa vaivaa paikoittain kuitenkin esiin pistävä historioitsijoiden tauti eli taipumus diakroniseen luettelointiin. Struktualisti haluaisi etsiä synkronian tasapainottavaa humoraalia, esimerkiksi tyyppien vertailua (kuten kylmä ja kostea nainen, kuuma ja kuiva mies) annetussa laajemmassa järjestelmässä. Valtio-oppinut taas ei voi olla miettimättä esimerkiksi Joutsivuon mainitseman Alkmaion Krotonilaisen voimien isonomia -ajatuksen yhteyttä poliittiseen isonomiaan ja sitä kautta poliittiseen kosmoksen tulkintaan, jota erityisesti Ranskan ja Italian antiikin tutkijat ovat korostaneet. Varsinkin kun (seikka, jota ei kirjassa mainita) Alkmaionilla ajatus luonnollisesta isonomiasta asettuu vastakkaisena monarkian taudille. Alkmaionin onkin nähty puhuvan enemmän Krotonin poliittisesta tilanteesta kuin 
lääketieteestä, ja yhteyksiä on haettu myös Alkmaionille suuhun laitetun, myöhemmin Aisopoksen nimissä esiintyvään tarinaan, jossa ihmisruumiin elimet jättävät luonnollisen isonomisen järjestyksensä ja antavat yksinvallan yhdelle näistä aiheuttaen koko ruumiin sairastumisen. Alkmaionin ajatuksen on nähty myös viittavan taisteluun Klinian tyrannian puolustajien ja vastustajien välillä ja osoittavan muuten pythagoralaisista eroavan Alkmaionin liittymistä näihin tyrannian vastaisuudessa. ${ }^{+}$ Erwin Panofskystä innostunut taas ei voi olla etsimättä elementtien laajempia yhteyksiä filosofiaan ja yleisiin ajattelumuotoihin. (Varsinkin kun Galenoksenkin ja erityisesti sittemmin Avicennan ja Averroeksen tapauksessa on mahdotonta erottaa lääkäriä ja filosofia.) Kyse on tietenkin vain yksityisistä mielipiteistä ja suhteellisen spekulatiivisesta ideoiden etsinnästä, joka ei välttämättä ole ja jonka varmasti ei tulekaan olla historian tutkijoiden tavoite.

Tämä koskee myös liiallista spekulaatiota Joutsivuon Galenokselta esiin nostaman hienon neutrumin ja neutraalin kehon käsitteen kohdalla, jota Joutsivuo tosin itsekin esittảa varovasti yhdeksi mahdolliseksi uudelleenajattelun kohteeksi ja jonka nousua ja häviötä hän kuvaa. Käsite, joka eli lähinnä Galenoksen Ars Parvanja Avicennan Kaanonin luennassa, hävisi vähitellen 1600- ja 1700-luvun aikana, mutta menetettyään jo aikaisemman asemansa ja tulkittuna nyt heikentyneenä terveytenä, siis negaation kautta. Neutraali tila ei nimittäin aikaisemmin suinkaan tarkoit- tanut sairauden poissaoloa tai täydellistä terveyttä vaan juuri sairauden ja terveyden sekoitusta. Se oli terveen ja sairaan "välissä" binaariopposition rikkovana "kolmantena tilana" olematta (ymmärtääkseni) myöskään niiden keskivaihe vaan samanaikaisesti kummastakin osallinen (tuolloin sairas, tällöin terve). (Tässä olisi mielenkiintoista tietää neutrumin mahdollinen yhteys Platonin ideaopin keskiaikaiseen luentaan.)

Joutsivuon mukaan myöhäiskeskiajan Ars Parvan kommentoinnissa keskeiseksi neutrumin lisäksi nousi erottelu simpliciter (absoluuttisesti) ja ut nunc (tällä hetkellä). Torrigianon tulkinnassa simpliciter määrittyi juuri terveenä tai sairaana, kun taas ut nunc kuului eri kategoriaan. Kuitenkin Torrigiano oli sitä mieltä, että $u t$ nunc ei tarkoittanut vain terveyttä tällä hetkellä vaan viittasi äärettömällä ajan jatkumolla mihin hyvänsä toteutuneeseen terveydentilaan. Yleisesti simpliciter asettui kykynä ja ut nunc muuttuvana dispositiona. Joutsivuon mukaan nämä voidaan tulkita pitkälti potentiaalisuudeksi ja aktuaalisuudeksi. Neutrum näyttääkin kiinnittyvän juuri ut nunc -tilaan, mutta ei suinkaan puhtaana aktuaalisaationa vaan siirtymänä. Voitaisiinko siis antaa ajatuksen lentää ja sanoa, että neutraalikeho on virtuaalikeho, ei potentiaalinen eikä aktuaalinen vaan puhdas siirtymä, ei sairas tai terve ruumis vaan eräs ruumis tai kenties jopa quodlibet, mikä tahansa. 1500-luvulla esitettiinkin, että jos neutrumin käsite hylätään, joudutaan luopumaan toipuvien ja sairastuvien kehojen käsityksestä.

Juuri sairastuvien ja toipuvien kehojen käsite onkin ollut vaikea suoltaa myöhemmälle länsimaiselle terveysajattelulle, jossa terveys on usein ollut puhtaasti sairauden puutetta, "orgaanien hiljaisuutta" ja jonka "nihilismi" perustuu orgaanien äänen loputtomaan vaimentamiseen. Näin eräs ruumis uhrataan aina terveyden alttarilla, vaikka yksikään uhri ei voi vaimentaa lopullisesti orgaanien huutoa. Siksi vaikka kristinusko tekikin "orgaanien huudattamisesta" (Simeon Pylväspyhimyksen liallisesta seisomisesta lihan läpi repeytyvät luut) perverssin kivunrakkauden kautta tapahtuvan hengen pelastuksen, niin samalla sille on annettava pisteet sen osoittamasta sairauden sietokyvystä, jota antiikin julmuus (Platonin karaistuminen, joka pudottaa heikot pois) tai moderni ekonomistiikka (vammaiset ovat ok, jos heidät saadaan tuottavaan työhön lievittämään sairauden yhteiskunnallisia kustannuksia) ei tunne. Joutsivuo käsittelee myös kristinuskoa ja korostaa Nuttonia seuraten siinä tapahtuvaa syn.nin ja sairauden yhdistämistä. Mutta toisaalta tuo synnillinen ruumis, lihan heikkous, oli myös yhteinen nimittäjä, joka toi myös sairaat, köyhät ja vaivaiset ainakin periaatteessa samaan asemaan mahtavien kanssa. Joutsivuo korostaa myös Kristuksen näkemistä lääkärinä ja pelastajana, jolla oli helleeninen esikuva Asklepioksessa. Tässäkin voisi korostaa tapahtunutta siirtymää; käsittääkseni Kristuksen ihmeparannus ei kuitenkaan vastaa Asklepioksen voimaa. Asklepios paransi puhtaalla 
jumaluudella. Terveyden jumalan funktio oli parantaminen, ja pelkkä usko ilman Asklepiosta ei riittänyt parannukseen. Kristus taas paransi uskon kautta, ja voimakas usko ilman jumalan läsnäoloakin riitti ihmeeseen. Kristus ei ollut erityinen parantajajumala, vaan kokonaisen uuden kaikkivaltiuden sanansaattaja, jonka (juuri uskon-) voimasta parannus oli vain yksi merkki. Siksi myös hippokraattinen lääketiede pystyi elämään suhteellisen rauhassa kristinuskon rinnalla, joka ei suinkaan pyrkinyt olemaan sen kilpailija maallisen terveyden tuottamisessa.

Kristus siirsi parantajavoimansa apostoleilleen uskon levittämisen tehtävän kanssa, ja tämä "kaikkivallan" parantava voima oli myös teokraattisen emanaation kautta kristillisten kuninkaiden ominaisuus, joiden parantavaa kosketusta Marc Bloch on erinomaisessa teoksessaan käsitellyt. Sen sijaan hallitsijaoppaiden traditiossa kysymys oli aina ollut hallinnan "keston" turvaamisesta maan päällä. Renesanssilääketiedettä koskevassa artikkelissaan Mikkeli mainitsee tähän "itse-reflektion peilejä hallitsijoille" tarjonneeseen traditioon kuuluneet renessanssin ruhtinaiden käytösoppaat maaperän valmistelijoina hoito-opastraditiolle. Juuri hovien käyttöön kirjoitetut terveysoppaat jatkoivat opaskirjojen perinnettä, mikä poliittisen elämän ohjekirjojen osalta hiipui jó 1500-luvun alkupuolella. Terveyden tasapainotila ja pitkä elämä oli oppaiden keskeisenä tavoitteena. Mikkeli korostaa myös uuden kansanterveydellisen julkisen hygienia- liikkeen nousua 1800-luvulta lähtien ja tämän liikkeen eroa antiikista periytyvään dietetiikkaan. Tähän väliin sijoittuukin Heikki Lempan analyysin kohteena oleva saksalainen 1700-luvun kasvatusperinne, joka oli Lempan mukaan olennaisesti vielä lääketieteellisen dietetiikan eli elämänjärjestyksen tuote.

Lempa pyrkii käsittelemään Saksan 1700-luvun filantropismia, tätä yleiselle ihmisrakkaudelle perustuvaa kasvatus- ja sivistysliikettä, mielenkiintoisesti juuri sekularisoitumisen näkökulmasta tai paremminkin sakraalin alueen uudelleenmäärittelynä (ihmetekojen rajaus ja toisaalta sakraalin vallan uudelleenmäärittely maallisen vallan palvelukseen, missä uskonto esiintyy nyt yhteiskunnan yhtenäisyyden ja moraalin takaajana) teologian pedagisoinnin kautta, mikä muodosti filantropistisen liikkeen teoreettisen perustan. Sekularistiseen ihmiskäsitykseen pyrkivä liike jäi kuitenkin lyhytikäiseksi leimauduttuaan Ranskan vallankumouksen jälkeen piilovallankumoukselliseksi ja jouduttuaan ankaran sensuurin kohteeksi. Lempan mukaan liike sijoittui toisaalta aristokraattisen kunnian estetiikan (etiikan) ja toisaalta alaluokkien kurinalaistamisen väliin jäävään tilaan, joka alkoi täyttyä 1700-luvun lopulla aivan uudenlaisesta affektikulttuurista ja joka kiinnittyi kouluissa ja kasvatusinstituutioissa sosiaalistuvaan luokkaan. Voitaisiinko siis puhua juuri keskiluokan affektitalouden järjestämisestä, keskiluokan, jonka terveys tasapainotteli aristokratian ja alaluokkien ääripäiden välillä ja johon voi- taisiin nähdä liittyvän erottautumisen estetiikan sijaan pikemminkin myös vaatimus keskinkertaisuudesta (Mittelmäßigkeit) ja turvautuminen "jokamies"-argumenttiin. Lempa mainitsee juuri siveelliset säädyt (gesitte Stände) tämän valtiollisen ja sivistysporvariston intressien välillä luovivan filantropistisen kasvatuksen kohteena ja korostaa tätä erityisesti maskuliinisena sivistyneistönä, miehisyyttä ja karaistumista alleviivaavana vastakohtana ranskalaisen hovikultuurin naiselliselle keikaroinnille. Mutta onko kyse vain maskuliinisuuden korostamisesta vai "keinotekoiseksi" nähdyn vastustamisesta, kuten hovitanssin kritiikissä vartalon keinotekoisesta asennosta ja jäsenten hienostelevista liikkeistä? Lempa mainitsee nimittäin itse lastaan imettävän äidin ("luonnollistetun" äidin) olleen samanarvoinen tämän miehisen dynaamisen ja aggressiivisen liikunnan itsensä ihailun kanssa. Olisiko siis kyse modernin yli kaksi vuosisataa jatkuneesta keinotekoisen järjestyksen kritiikistä? Eikö juuri tähän liity "kuolleiden" kielten (latinan ja kreikan) ja tradition hylkääminen ja modernien kielten, luonnontieteiden, maantieteen, historian, äidinkielen ja liikuntakasvatuksen korostus sekä toisaalta näiden liittäminen valtion materiaalisen voimistamisen projektiin. Lempa huomauttaakin, että maantieteen tehtävä ei ollut niinkään lisätä geografista päättelykykyä vaan opettaa isänmaan rajat ja että liikunta ja moraalikasvatus taas pyrkivät lisäämään suorituskykyä. Tämä on tietenkin myös foucault'laisen biovallan teema, johon ei suin- 
kaan liity affektien kieltäminen (alistushypoteesi), vaan niiden tuottavuuden ohjaaminen (biovalta). Lempa kritisoi aiheellisesti Eliasta ja tämän seuraajia sekä halun yksinkertaisesta tulkinnasta että pitäytymisestä puhtaassa alistushypoteesissa. Mutta korostaessaan affektien poiskitkemisen sijaan niiden hyödyntämisen teemaa on Lempa itse asiassa hyvin lähellä Foucault'ta, jonka hän niputtaa Ostreichin kanssa lähinnä absolutistisen kurinpitojärjestelmän analysoijaksi ja alempien luokkien halutalouden synty-yhteyden hahmottajaksi. Lempan mukaan kasvatusliike taas oli ensisijaisesti niiden ryhmien ja luokkien affektitalouden malli, jotka sosiaalistuivat kouluissa. Se ei avaudu palkkatyön etiikasta käsin vaan juuri sivistyneistön karaisemisena, jota ei oltu tarkoitettukaan työyhteiskunnan kurijärjestelmään. (Kuria ei tulisikaan kảsittää pelkkảnä kehittyvản teollisen kapitalismin vaatimuksena vaan juuri itsehallinnan kautta tapahtuvan hallinnan alueen luomisena.) Lempa viittaa tässä myös Hirschmanin tunnettuun esitykseen, jossa tämä tutki "kapitalismin mảhdollisuusehtoja" siirtymisenä vaaralliseksi paheiksi nähdyistä intohimoista positiivisemmin käsitettyihin ja viattomampiin laskelmoitaviin intresseihin. Historioitsija tietenkin haluaa tähdentää, ettả filantropisessa affektirakenteen muutoksessa kysymys asetettiin hieman laajemmin eikä kyse ollut niinkään muutoksesta yhden affektitalouden sisällä vaan valinnasta kahden affektikulttuurin välillä. Kyse oli uudenlaisen työn etiikan etsimises- tä, jota kutsuttiin yrittämisen haluksi ja jota ei niinkään luonnehtinut kepeä kaupankäynti kuin säästäväisyys, ahkeruus, taitavuus ja uutteruus ja joka kiinnittyi juuri pikkukaupunkien käsityöläisporvaristoon.

Kiinnostava osio Lempan artikkelissa on myös unen ja valveen väliin jäävän horroksen tiukan kontrolloinnin käsittely. Kasvatusliike korosti nopeaa ja varhaista herätystä sekä ruumillista työntekoa ennen kuin aamiaisen kautta siirryttiin tavanomaiseen päiväjärjestykseen ja vastaavasti illalla nukahtamisen ankaraa valvontaa. Seká mielen että ruumiin nähtiin tuottavan mielteitä (Vorstellung). Mielen mielteet viittasivat selkeään kohteeseen, ja myös osa ruumiin mielteistä oli selkeitä, kutèn nälkä, jano ja vilu. Ongelmana olivat mielteet, jotka eivät olleet kauttaaltaan tällaisia, kuten seksuaalinen halu. Aikuisella se oli selkeä ja löysi kohteensa lisääntymisestä, mutta lapsilla se oli jotakin muuta. Lempan mukaan ongelmaksi nousee seksuaalisuus sinänsä, pelkkänä intohimona ilman selkeää kohdetta. Unen ja valveen välimaille jäävä horros on juuri tämän päämäärättömän seksuaalisuuden tila, jossa mielteitä ei kyetty vielä kontrolloimaan. Ja kuten tiedämme, juuri horroksessahan unen ja päivän selkeys sekoittuu unettomassa unessa, insomniassa, jolloin ajatus lähtee omille teilleen ja ainakin miehen ruumis saa oman autonomiansa.

Tämä tuo tietenkin mieleen munkkien "keskiajan suurimman vitsauksen", kuolemansynnin ja myös erektion nostattavan tilan eli keskipäivän demonin, acedian, jolloin ajatukset lähtevät harhailemaan (evagatio mentis, mielen harhailu) fantasiasta fantasiaan vailla kykyä kiinnittää järjestys ja rytmi ajatteluunsa. ${ }^{5}$ Munkki ei jaksa keskittyä lukemaansa, vaan levottomana siirtää katseensa kirjasta seinään vaipuen tyhjiin haaveisiinsa. "Moderni psykologia" haluaisi tulkita acedian vain syyllisyydentuntoiseksi laiskan uneksi ja synniksi kapitalistista työnetiikkaa kohtaan. On unohdettu, että acedia asetettiin ahdistavan surumielisyyden ja toivottomuuden tunteen yhteyteen. Se on surumielisyyttä suhteessa ihmisen olemukselliseen henkiseen hyvään, ja näin kyse ei ole niinkään pahan ajattelusta vaan suurimman hyvän mietiskelystä, mielen perversiosta, joka haluaa objektia ilman siihen johtavaa tietä. Halu sulkee itseltään tien saavuttamattoman objektin mietiskelyllä, ja ongelmana on haluta kaikkea jaksamatta nähdä vaivaa. Tilaan liittyvä pään notkahdus ei siis kerro niinkään laiskuudesta kun toivottomuudesta pakenemattoman tilanteen, kuolevaisten kohtalon edessä. Mutta tássä on myös sen positiivisuus; tila asettuu myös pakona individuaatiosta ja omistamisesta kohti saavuttamatonta ja sitä omituista toivoa, joka on annettu kaikille toivottomille.

Nain voimme löytää yhteyden kirjan alussa käsiteltyyn melankoliaan, ja keskipäivän demoni munkkien tautina ja melankolia erityisesti oppineiden (runoilijoiden ja filosofien) vaivana löytävät toisensa. Kuolevaisuuden riski, joka liittyy tiedon erotiikkaan ja haluun kohti saavuttamatonta, yhtyy myös tuohon päämää- 
rättömään seksuaalisuuteen ja kertoo eroottisen halun ja melankolian antiikkisesta yhdistämisestä. Aristoteleellahan seksuaalinen kiihotus johtuu hengityksestä/hengestä, josta todistaa peniksen kasvaminen pienestä suureksi. Ja, Lempan artikkeliin palataksemme, hän toteaakin unen ja valveillaolon säätelyn liittymisestä keskusteluun ilmasta ja nyt erityisesti säästä ja huoneilmasta. Nyt siis ilma, joka perinteisesti oli liittynyt elimellisesti oppineiden terveyteen yhdistymällä järjen kantajaan, pneumaan, henkeen, oli menettänyt tämän merkityksensä ja oppineiden elämäntapa edusti enää ainoastaan huonoa ilmaa, ummehtuneisuutta, kirjallista kulttuuria, ahdasmielisyyttä ja sosiaalista sulkeutuneisuutta. Materialisoituneessa ja läpipornografisessa kulttuurissamme penistä ei tietenkään enää nosta henki vaan terveiden ja kiinteiden lihamassojen esilläolo.

\section{KULTTUURISIA KURIOSITEETTEJA}

Toisessa osassa siirrytään elämäntavan ilmiöiden kuvailuun eli "mikrohistoriallisempaan" ja "kultuurisosiologisempaan" muotoon. Kai Häggman kertoo hauskana kuriositeettina mielenkiintoisen tarinan Waseniuksien "vissyveden" juonnista. Tosin juttuun olisi kaivannut hieman enemmän näkökulmaa, vaikkapa juuri Häggmanin mainitseman keskiluokan sisäistetyn hallinnan teeman kehittelyn kautta. Riitta Oittinen taas kertoo hauskoja tarinoita patenttilääkkeistä, ihmepillereistä, näistä moderneista Caton kaaleista, joista ajateltiin löytyvän pelastus lä- hes kaikkiin ongelmiin, ja voidaan todeta, että jos terveys tuo pelastuksen, niin sairaus tuo ehtymättömän bisneksen. Tämän ovat tietenkin nykyiset hippokraattisen ideaalin köyhästä ja ilmaiseksi parantavasta lääkäristä kokonaan unohtaneet lääketehtaiden konsulttilääkärit hyvin sisäistäneet.

Turo-Kimmo Lehtonen taas käy henkisten ruttotautien siementen kimppuun jäljitellessään modernin homo hygiensin syntyä eli sitä miten terveydenhoidon tavat pyrittiin juurruttamaan Konrad Relanderin sanoin "meidän toiseksi luonnoksemme". Kyse on hygieniasta koko kansakunnalle osoitettuna ohjelmana, joka soveltavana tieteenä pyrki välittämään hygieeniset näkemykset kansanterveyden hallinnoinniksi. Terveys ei asetu niinkään distinktiivisessä merkityksessä vaan demokraattisena huolen yleistämisenä, sen asettamisena yhteiseksi asiaksi, julkisen ja poliittisen huolen kohteeksi. Ohjelmana oli muokata koko kansan elintavat ja luoda uusi ihminen, mutta kyse oli "luonnollisemman" ihmisen luomisesta, jonka ilmaantumista vanhat keinotekoiset tavat vastustivat. Siksi ne oli kitkettävä pois uusien "luonnollisempien" tapojen juurruttamisen tieltä. Ihmiset piti opettaa "luonnonmukaisemmiksi" elinvoiman hyödyntämisen tähden ja elämän nimissä tapahtuvan hallinnoinin seurauksena. Lehtosen ansiona on puhtaan kuvauksen sijaan pyrkiä myös pohtimaan tätä elämän ja elämänvastaisuuksien antinomioissa pyörivää ajattelua. Tosin välillä asioita olisi voinut ilmaista ytimekkäämmin ja todeta, että taustalla on (näin ainakin oletan) uusi fysiologinen näkemys organismin patologiasta, jossa kuolema ei asetu elämän suhteen toiseksi, vaan sen ytimeen kuuluvaksi elämän itsensä ehdoksi, elämän asettuessa nyt juuri kuoleman resistanssiksi. Taistelu tauteja vastaan on juuri taistelua organismin vastustuskyvyn ja elinvoiman puolesta, sen normaaliksi katsotun kehityksen tukemista degeneratiivisia kuolemaan johtavia kehityskulkuja vastaan. Vastaavasti elämän arvoon liittyvän kysymyksen voisi kai nähdä erillisen transsendentin viitepisteen häviämisen ongelmana, jolloin elämästä itsestään tulee "hyvän" ja "pahan" sisältämä kaksoisidos.

Kuten Lehtonen toteaa, terveydestä tulee itseisarvo, mutta kuitenkin arvo, joka liittyy sekä yksilön että yhteiskunnan menestykseen elämäntaistelussa. Terveys on korkoa kasvavaa pääomaa ja elämänvoimaa, puhdasta kykyä, jota voidaan menestyksekkäästi hyödyntää. Hyödyntäminen tarkoittaa kuitenkin ennen kaikkea työtä, ja juuri laiskuus, saamattomuus ja henkinen velttous on vaara terveydelle. Työn rasitus, joka kai yleensä on tappanut työläiset nopeammin kuin herrat, on tässä jälleen karaisevaa ja terveyttä lisäävää toimintaa. Relanderille terveyden arvostaminen on lähtökohta työteliäisyydelle ja tehokkuudelle, omien kykyjen kehittämiselle, jota "kalvinistisesti" seuraa myös maallinen menestys. (Sarasvuon suosio voisi siis viitata myös Konradin uusintapainosten mahdolliseen myyntimenestykseen.)

Kyse on myös ihmiskuntaa
$<$ 
yhdistävästä sodasta uutta yhteistä vihollista, bakteeria, vastaan, jonka kansantajuistamiseen terveydenhoitolehdissä pyrittiin. Ja kuten Lehtonen hienosti kirjoittaa, luo bakteriologia kokonaan uuden ruumiin aistimellisuuden, jossa tartuntaa pelkäävä kosketus saa uuden merkityksen. Lehtosen mukaan bakteeri ilmaantui kaikkien vihollisena, suurena demokraattina, joka ei katsonut ikää tai yhteiskuntaluokkaa. Tähän voidaan tosin huomauttaa, että verrattuna miasma-teoriaan, jonka bakteriologia syrjäytti, ei kyse ollut niinkään suuresta demokraatista. Vaikka ero ja vertailu ei varmastikaan asetu Lehtosen käsitelemässä terveyslehden aineistossa, on "mikrosta makroon" tapahtuvan siirtymän kautta mielenkiintoista korostaa myös bakteriologian tuomaa kansanterveyden logiikan muutosta sitä edeltäneisiin miasma-teorioihin. Niiden mukaan tauteja aiheuttava miasma piili likaisissa olosuhteissa ja huonossa, paikoillaan olevassa ilmassa. Parannus oli ympäristön puhdistamisessa ja tuulettamisessa. Sairauksia hallitakseen oli hallittava tilaa, ja miasma jätti meille korkeat huoneet ja leveät kadut, mutta myös asuinolosuhteiden parantamisen. Se sai tukea liberalismin ajatuksesta tavaroiden ja ihmisten vapaasta liikkuvuudesta, ja miasmojen tuuletus suosi dynaamista ja liikkuvaa tilaa. Bakteriologia taas antoi kansanterveydelle tieteellisen statuksen antamalla epidemioille oman objektiivisen ruumiin, "näkymättömän näkyvän", bakteerin, joka vaikutti ilmiöiden alla ja kulki ihmisistä ihmisiin mutta myös eritteli, erotellen muun muassa ih- misten ja eläinten tauteja. Toisin kuin yleiset miasmat se kiinnittyi juuri tiettyihin yksilöihin. Ympäristön puhdistamista tärkeämmäksi tuli ihmisten suhteiden hallinnointi, käytöksen kontrollointi ja riskiryhmien määrittäminen. Itse asiassa nyt liikkuvuuden paikat ja välineet, esimerkiksi asemat tai raha, olivat juuri vaarallisia tartunnan solmukohtia. Bakteriologia julistikin olevansa täsmäase, joka ei tehottomasti ammu sinne tänne vaan erityiseen taudin lähteeseen. Se etsi tartuttajaa, joka oli eristettävä ja hoidettava. Yleisen elinolosuhteiden parantamisen sijaan kysymys oli erityisten tautien kontrolloinnista. Kyse oli myös tautien muutoksista ja niihin asettuvista vastauksista miasma-toimenpiteiden osoittautuessaitse asiassa tehokkaiksi vuosisadan alun koleran hillitsemisessä, kun taas vuosisadan lopun tuberkuloosia ei parannettu ympäristöreformeilla vaan etsimällä tuberkuloosin kantajat. Kolerasta ei olisi voinut tulla sitä yksilöllisen kokemuksen muodostavaa tautia, joka tuberkuloosista tuli vuosisadan lopussa. Koleraa ei olisi voitu tulkita degeneraation tai heikkouden merkiksi, ja vaikka se olisi voinut antaa Taikavuoren insinööri Hans Castropille töitä puhtaan tilan suunnittelussa ja rakentamisessa, se ei koskaan olisi voinut antaa tälle sitä yksilöllistettyä hohdetta, joka korotti tämän tautinsa puolesta lähes taiteilijoiden kastiin.

\section{VALLAN DIAGNOOSI}

Lehtosenkin käsitteleman hallinnan teeman kautta päästään viimeiseen kriittisemmän nä- kökulman ohjaamaan osaan. Minna Uimosen hyvin asiallinen kuvaus hypokondriasta, hysteriasta ja neurasteniasta esittelee ansiokkaasti käsityksiä näistä taudeista ja on varsin mielenkiintoinen, vaikka sitäkin vaivaa hieman näkökulman puute. (Lukuunottamatta pyrkimystä sukupuolija luokkajaon esiinlukemiseksi, kuten neurasteenisten miesten oireiden somaattisuuden korostus ja itsekeskeisyyden tulkinta hypokondriassa "maailmasta vetäytymisenä", kun se taas hysteerikkojen, näiden suurten näyttelijättärien ja väärän mimetiikan mestarien tapauksessa näkyy lähinnä poikkiteloin asettumisena ja oikutteluna.) No, on neurastasia kuriositeettinakin mielenkiintoinen, ja löysin itselleni sopivan diagnoosin taudista, jonka oireina ovat päänsärky, vastavaivat, selkäkipu, itsehillinnän ja keskittymiskyvyn puute, ärtyvyys, unettomuus, väsymys, alakuloisuus ja vakava sairauden pelko ja joka kuvasi sensitiivisen hermoston omaavan, aivotyötä tekevän urbaanin miespuolisen yläluokan (kunniallista, jopa tavoiteltavaa ) ylirasittumista, mikä johtui luultavasti aivojen, ruoansulatusjärjestelmän ja sukupuolielimien liiallisesta käytöstä. Aikamme vääryyttä on, että nykyään kyse on subjektiivisesta psykosomaattisesta harhasta, kun Beardilla miehinen sukupuoleni olisi taannut oireille perustan objektiivisesti todennettavista hermofysiologisista ilmiöistä.

Aikakauden vääryyksiin käy käsiksi myös Mika Ojakangas, joka on huolissaan pahantapaisuuden sopeuttajista. Ojakangas kertoo tarinan lapsuuden tulemisesta keskei- 
seksi valtiollisen huolen ja hygienian kohteeksi ja tuon hygienian siirtymisestä ruumiista sieluun. Se on tarina lainsäätäjän ja tottelijan, klassisen kansalaisen, häviämisestä ja sopeutuvan lapsen synnystä, elämän terveestä ilmaisusta, jonka on sopeuduttava sekä sisältä kumpuaviin elämän vaatimuksiin (psykologisiin ja biologisiin kehityslakeihin) että ulkoisiin yhteiselämän ja ympäristön asettamiin sosiaalisiin vaateisiin (sosiaaliset normit) ja jonka ideaalityypistä on puhdistettu kaikki elämän normin rikkova suvereenisuus. Ojankankaan käsittelemä sielunterveydenhoito eli mentaalihygienia oli osa yleistä ennaltaehkäisevää, samanaikaisesti yksilöivää ja totalisoivaa (väestöä kokonaisuudessaan koskevaa) hygieniaa. Tämä valtiolääketiede oli ihmisyyden nimissä tapahtuvaa ruumiillisen ja henkisen työkyvyn ylläpitoa. Yleisen hygienian sijaan mentaalihygienia kiinnitti huomion sisäisen puhtauden ylläpitämiseen ja pyrki varmistamaan sielullisesti normaalin ihmisen kehityksen. Ennaltaehkäisyn oli kiinnityttävä vaaroihin jo ennen niiden aktualisoitumista. Rikollisuutta ei poistettu rikollista luonnetta paaduttavilla (karaisevilla) rangaistuksilla, vaan sitä oli ennaltaehkäistävä jo sen merkkien ilmaantuessa. Tehokkaan ennaltaehkäisyn oli siis kiinnityttävä puhtaaseen potentiaalisuuteen, lapseen, yhteiskunnan siemeneen ja tulevaisuuden toivoon. Lasta oli pidettävä silmällä, muttei sen tähden, että tämä muuten sortuisi pahantekoon (kuten aikaisemmin), vaan koska oli nähtävä aikaisin mahdolliset poikkeavuuden merkit, yhteiskunnanvastaisuuden muodot. Näin pienistä lasten käyttäytymisen muodoista intensifioitui tärkeitä julkisen huomion kohteita. Vauvojen kiukusta sekä pikkupoikien ja tyttojen hienovaraisista luonne-eroista tuli yhteiskunnallisesti merkittäviä asioita. Uusi tiedonmuoto synnytti uuden hahmon, vaikean lapsen, joka erosi edeltäjästään pahantapaisesta lapsesta siinä, ettei kyse ollut niinkään tavasta (paremminkin käyttäytymisestä) tai pahasta. Vaikeus ei määrity niinkään "pahuutena" tai sääntöjen rikkomisena vaan poikkeamana normaalista. Vaikea lapsi on myös "patologisen kiltti", passiivinen alistuja, mikä saattoi olla sielullisen sairauden alkuoire. Normaalin käsitehän on totaalinen ja ottaa kaiken alaansa, ja siksi vaikeita lapsia ovat kaikki lapset, sillä jokaisesta saattoi kehittyä ongelmalapsi, ja siksi psyykillisen hygienian ehkäisevä merkitys oli laajennettava myös "normaalien" lasten ongelmien selvittämiseen. Hyvän ja pahan sijaan kyse on nyt elämän immanentin normin vastaisuudesta. Mutta normaalius on fiktio, olettamus, joka tiedettiin epätarkaksi, eli kuten Margit Borg esitti: "Normaalius ja epänormaalius ovat suhteellisia käsitteitä." Normaalitkin lapset poikkeavat toisistaan, ja jokaisessa meissä on samoja luonteenpiirteitä kuin psykopaatissa. Kuten Saussuren kielisysteemi, normaali on tässä ilman positiivista termiä, ja jokainen lapsi suhteutui vain muihin lapsiin normaaliuden ja patologisen sulautuessa toisiinsa ilman rajaviivaa. Normaaliuden määritys onkin järjestelmä ilman ulkopuolta, vaikka mentaalihygieenikot pyrkivät kiinnittämään sen ajatukseen "positiivisesta" perustasta, "yhden ja yhteisen" elämän terveestä kehityksestä.

Tuon kehityksen poikkeamia oli etsittävä pienimmistäkin merkeistä. Kynsienpureskelu ei sinällään ole vaarallista, onhan se melutontakin, mutta kyse ei ollutkaan vain muihin häiriöihin viittaavasta merkistä vaan mahdollisen radikaalimman häiriön oireesta, jonka taakse on tunkeuduttava. Ei riitä tietää, miten lapsi käyttäytyy, vaan kysymys on siitä, mitätuo miten kertoi siitä, mitä lapsi on. Psykopaatti asettuu ääritapauksena, jossa miten ja mitä ovat yhdistyneet korjaamattomasti, eikä tämä sairaus olekaan parannettavissa, vaan kyse on pysyvästä poikkeavuudesta. Psykopaatti on tietenkin myös erityisen vaarallinen yksilö, koska kyse ei ole harmittomasta vähäälyisyydestä vaan jopa tietystä "nerokkuudesta", eli, kuten Borg muistuttaa Hörderlinin jakomielitaudista ja muiden sairaiden taiteilijoiden elämäntyöstä, nerokkuudesta, joka teki näistä yhteiskunnalle erittäin vaarallisia. Vaaran taustalla eivät ole ainoastaan perinnölliset piirteet vaan kasvatusvirheet, ja siksi tiedon puutteesta kärsiviä ja kasvatustehtävään sopimattomia vanhempia, aikaisempia kasvatuksen auktoriteetteja, on nyt ryhdyttävä kasvattamaan. Heitä oli valistettava uudesta hienovaraisesta kasvatuksesta, jota ei saa olla liikaa eikä liian vähän. Kasvatusneuvolat nousivat tämän ehkäisevän sielunterveydenhoidon etuvartioiksi ja kotikasvatuksen neuvontakeskuksiksi. Julkisen 
huolen kohteeksi ei asetettu vain pientä lasta vaan perheen sisäiset tunteet. Huolena eivät olleet vain aineelliset, hygieeniset tai siveelliset puuutteet (hyvä koti ei muodostu vain palkkapusseista, puhtaista lakanoista ja siveellisestä vaelluksesta); lisäksi oli paljon hienovaraisempi huoli kodin elämyksellisten tunteiden laadusta ja määrästä. Hyvää kotia määritti vanhempien tunnepitoinen suhtautuminen lapsiin ja tunnepitoisten elämysten terveys, eiväthän vanhemmat olleet enää vain kasvattajia vaan lapsi-organismin psykologinen ympäristö. Normaalius ei synny viettien ja himojen (eläimellisyyden) kahlinnasta siveellisen järjen nimissä vaan oikean tunnesävyisen asenteen opettamisesta ympäristón suhteen. Oikeus ilmaista tunteitaan oli yksi uusia omituisia oikeuksia, ja keskeiseksi nousi klassisesti epápoliittinen tunne par excellence eli rakkaus. Myös rakkauden voima oli asetettava normalisaation välineeksi ja tehtäväksi tuli määrittää normaaliin kehitykseen kuuluva sopiva rakkauden määrä.

Rakkaus oli myös avioelảmän päämäärä ja ohjailun kohde siinä empiirisiin ja luonnontieteisiin, biologiseen ja psykologiseen asiantuntemukseen perustuvassa modernissa pariutumisen etiikassa (Helénin termi), joka asetti hienovaraisen katseen rakkauden muotojen normaalistamiseen, määritti varsinkin naisen itsesuhdetta, ruumiista ja persoonallisuutta, mutta jonka keskiössä oli sukupuolielämä ja erityisesti tyydytetty (miehen uusi yhteiskunnallinen vastuu) ja oman terveen seksuaalisuutensa tunteva ja kokeva naissubjekti. Ilpo Helénin diagnisoiva katse ja diskurssi tunkeutuu naisen orgasmin ongelman hahmottumiseen modernissa scientia sexualis -muodostelmassa, jossa orgasmista tuli yhteiskunnallisen huolen aihe ja sen puutteesta yhteiskuntajärjestystä horjuttava tekijä.

Helén aloittaa hienolla alkukontrastilla, joka asettaa vastakkain juuri antiikin humoraalipatologian ja meidän aikamme kylmän naisen osoittaen ne täysin eri "historialliset kudelmat", joissa nämä näennäisesti saman nimen omaavat hahmot asuvat. Kylmä nainen ei tarkoita enää vain humoraalista tosiasiaa naisen ruumiin viileydestä vaan kertoo naisen haluihin ja nautintoihin liittyvästä persoonallisuuden piirteestä, jonka ympärille rakentuu k’okonainen seksuaalikoneisto. Kyse on myös naisruumiin intensifioitumisesta ja nousemisesta yhteiskunnallisesti ja poliittisesti merkittäväksi tekijäksi tai biovallan teeman mukaisesti biologisen, sukupuolitetun ja fysiologisen ruumiin asettumisesta politiikan keskiöön ruhtinaan spektakulaarisen vallan ruumiin (oli se sitten Ludvig XIV:n tai Elisabeth II:n) sijasta. Antiikin kylmä ja vetinen naisruumis antoi kuumalle ja kuivalle miehelle keskeisemmän osan myös hedelmöittämisessä, ja siksi miehen ruumis ei ollut ainoastaan poliittisesti (julkisena hohtona ja sopusuhtaisen ruumiin arvokkuutena) vaan myös reproduktiivisesti (miehen antaessa varsinaisen hedelmöittämisen muodon ja hengen) naisen ruumista arvokkaampi. Biovallan tarina on taas naisen ruumiin esiin nostaminen, sen kontrollointi, mutta myös "vapauttaminen"; sen aktiivinen muokkaus, käyttö ja lopulta sen nautintojen oikeuksien määrittely. Tässä prosessissa käytiin vanhoja tapoja vastaan lääketieteellisen tiedon ja biologisten tosiasioiden avulla ja siirryttiin haluttoman naisen hahmosta naisen halujen normaaliuden ohjailuun.

Tosin käsitys luonnollisesti "haluttomasta naisesta" oli ollut omituinen uutuus kulttuurissamme, joka traditionaalisesti oli nähnyt naisen halun voimakkaampana, eläimellisempänä ja siksi vaarallisena (koska nainen ei osannut kontrolloida haluaan kuten sivilisoituneempi mies). Himo oli tosin antiikissa tärkeä tekijä siitostapahtumassa, jonka onnistumiseen tarvittiin kummankin osapuolen hekuma. Tosin Rooman valtakunnassa esiintyi vahva kritiikki hekumaa kohtaan, sillä ajateltiin arvokkaita lapsia tuotettavan vain arvokkaalla käytöksellä sängyssä; kristinusko taas teki todellisen ongelman miehen ruumiiseen ja elimeen paikallistetusta halusta. (Augustinuksella paratiisista karkotukseen johtaneen Jumalan järjestyksen tottelemattomuuden rangaistus oli juuri miehen ruumiin oma epäjärjestys, peniksen autonomia.) Moderni keskittyi taas vahvasti naisen ruumiin ongelmaan, mutta tuo ruumiis oli nyt biologinen, fysiologinen ja anatominen, ja sen kautta naisen olemus pyrittiin käsittelemään lähinnä munasarjojensa välityksellä. Kiimaa ei käsitetty enää välttämättomäksi hedelmöitykselle, ja kun ymmärrettiin, että munasolu irtaantuu spontaanisti ilman yhdyntää, ei haluton nainen ollut enää este 
reproduktiolle. Helén jäljittää ajatukset naisen haluttomuuden luonnollisuudesta valistusfilosofeihin sukupuolieron toimiessa luonnollisena perusteluna sille, että naiset rajattiin kànsalaisuuden ja julkisen järjenkäytön ulkopuolelle. Mutta jos Kreikassa naisen epäjärjestystä tuova tyrannimainen halu oikeutti "kotiuttamisen", niin valistuksesta lähtien "kotiuttaminen" pyrittiin esittämään naisen vaimeamman, luonnollisesti avioliittoon ja kodinhoitoon suuntautuvan halun pohjalta. 1800luvulla kiteytyykin ajatus naisen ja miehen erilaisuuden fysiologisesta, biologisesta ja anatomisesta perustasta. (Nainen ei ole enää vain puuttellinen mies vaan eri olento.) Nainen on synnytyselintensä määrittämä olento, jonka vietti on vaimeampi. Samalla prostituoidun hahmo ei ole enää vain moraaliton toimija, lihallisia halujaan kahlitsematon synnillinen olento, vaan luonnottoman halun ilmaus. 1800luvulla, samanaikaisesti kun prostituoiduista tulee vahvojen poliisitoimenpiteiden kohde, tapahtuukin uusi prostituoidun hahmon luominen, pyrkimys luoda empiirisen aineiston avulla kuva prostituoidusta. Huora ei ole enää vain herrojen fantasioiden romanttinen hedelmä vaan tieteellisen kiinnostuksen kohde, sukupuolitartuntojen lähde ja empiirinen tosiasia, jota tuli hallinnoida. Kontrolloitavan köyhälistöhuoran vastakohdaksi taas asettui haluttoman porvarisnaisen hahmo. Mutta porvarisnainen ei ole nyt niinkään kulttuurin tuote, luonnollisen himon kahlehdinnan jalostama, vaan itse asiassa lähempänä luontoa (vaimean halun nainen) proletarihuoran edustaessa nyt vääristynyttä luontoa. Ymmärtääkseni prostituutiokysymyksessä kohtaavatkin kaksi 1800 -luvun suurta kysymystä, jotka seurasivat oikoksen ja tuotannon nousua poliittiseen keskiöön teollistuneessamaailmassa: "sosiaalinen kysymys" ja "naiskysymys". Helénin mukaan erityisesti jälkimmäisen ympärille muodostui moderni sukupuoleen kiinnittyvä seksuaalipolitiikka. Sukupuoleen vetosivat sekä argumentit, jotka pyrkivät perustelemaan naisen sulkemisen opiskelusta ja työnteosta, että toisaalta naisen valtaa ja arvokkuutta korostavat diskurssit. Nyt kun antiikin käsitys oli käännetty päälaelleen, ja mies nähtiin eläimellisempänä ja viettiensä orjana, voitiin myös luonnollisesti intohimottomampi nainen ("luonnollista järjestystä" lähellä oleva hyvä nainen, äiti) nähdä moraalisempana toimijana ja eläimellisen miehen sivilisoijana. Näin naiselle olisi annettava valta päättää yhdyntöjen ajankohdista ja säädellä kodin järjestystä kuukautiskiertonsa mukaisesti. (Voin todeta että sama ilmiö toteutui rotuhygienisessä keskustelussa, jossa naiselle annettua keskeistä asemaa rodun ja kansakunnan vartijana voitiin käyttää sekä naisen reproduktiivisen potentiaalin äärimmäisenä kontrollointina (kuten kansallisosialismissa) tai myös naisten seksuaalisen vapauttamiseen, vapaan valinnan tuottaessa parhaan rodun jalostuksen (kuten "liberaalisemmassa feministisessä" rotuhygieniassa).) Luonnollisuuden sijasta naisen himosta oli tullut patologista ja tuon epänormaalin vietin ruumillistu- miksi nousivat vanhat tutut, tosin nyt "biologisoidut" tyypit kuten prostituoitu, kurtisaani ja nymfomaani, mutta haluttoman äidin vastakohdaksi nousi myös uusi hahmo, hermostunut nainen, bysteerikko. Hysteerikossa löydettiin myös nainen psykosomaattisena kokonaisuutena ja naisruumiin biologis-fysiologinen heikkous ja patologisuus siirtyi sielulliselle tasolle hysterian määrityksen muuttuessa kohdun liikkeistä keskushermoston patologiseksi tilaksi.

Helénin mukaan hysteerikkoa käsittelevät diskurssit olivat kuitenkin tie naisen halun uudelleenlöytämiseen ja ne marsittivat nyt areenalle mielihyvään ja nautintoon suuntautuneen seksuaalivietin. Tämä tapahtui ensisijaisesti poikkeavuuksien tutkimisen kautta (hysteerikkojen, mutta myös homoseksuaalien) siirtyen sitten myös koskemaan normaaleja muotoja (aviollinen heterosuhde). Seksuaalivietistä, ihmisissä vaikuttavasta elämänvoimasta, tuli yhteinen nimittäjä poikkeaville ja normaaleille, naisille ja miehille. Sukupuolisuus puhdistui sukupuolierosta viitaten jakamattomaan funktionaaliseen elämänvoimaan. (Seksologia olikin pyrkinyt soveltamaan darwinistisia ajatuksia ihmiselämään ja näin elämäntieteen tuntemiseen perustuvan elämänhallinnan kautta yhdistänyt itsensä myös lääketieteeseen.) Ja vaikka perustalla oli ajatus soluista, kromosomeista ja organismin funktioista löytyvästä ilmiöiden olemuksesta, niin ilmiöiden tutkimuksessa seksologia suuntautui juuri sielunelämään. Sukupuolisuudesta tuli ihmisen psyko- 
fyysisenä kokonaisuutena yhteen tuova tekijä, jossa yksilöllinen kohtasi lajityypillisen ja sosiaalisen, ruumin pinta sielun syvyyden, normaali epänormaalin ja kehitys rappeutumisen. Oltiin samoissa elämän antinomioissa, joita Lehtosen ja Ojakankaankin artikkelit osaltaan käsittelivät, ja ongelmassa, miten elämän normi asetetaan kun elämän määräämättömyys ei näyttänyt antavan sille mitään perusteita. Helénin mukaan yhtenä ratkaisuna pyrittiin viettielämän tarkempaan tutkimiseen, jonka johdosta viettiteoria muuttui sukupuoliteoriaksi. Tahtomattaan tämä teoria erotti lihalliset himot miehekkyyden ja naisellisuuden määreistä ja jäi usein päättämättömänä huojumaan sen välille onko vietti ontologisesti määräämätön vai sukupuolisesti eriytynyt. Seksuaaliteorioissa biologinen sukupuoli ja yksiavioinen jälkeläisiä tuotava avioliitto asettivat kuitenkin normaalin halun suunnan ja toimivat vietin järjestyksen periaatteena lääketieteellisen avioliittoneuvonnan maailmassa aina 60-luvulle asti. (Samoin gynegologis-neurologinen näkemys sai väistyä patologisten ilmiöiden etsimiseen tunne ja kokemusperäisistä häiriöistä ja yksilöllisistä psyykillisistä ilmiöistä. Siirryttiin ruumiillisesta kontrollista terapeuttisempaan kontrolliin.)

Helénin mukaan tässä sommitelmassa syntyi aviollisen pariutumisen etiikka, joka teki ruumiin nautintotalouden analyysin hienovaraisemmaksi kulkien sukupuolihygieniasta yhdyntätekniikoihin ja kiinnittyen ruumiin vietteihin ja niiden synnyttämiin haluihin.
Päämääränä oli yksilöiden elämää rikastuttava ja yhteiskunnallisesti tuottava täydellinen avioliitto. Sen etuvartioina toimivat avioliittoneuvolat ja -oppaat ja sen diskurssina oli seksologia, jonka oli parannettava avioelämää ja ohjattava terveeseen yksiavioiseen sukupuolielämään. Yksiavioisuuden oikeutusta ei tosin haettu enää patriarkaalisen perintälinjan säilyttämisen takaamisesta tai Raamatun käskyistä vaan biologiasta, antropologiasta ja eläintieteellisistä tutkimuksista. Kyse oli kehittyneimmästä eläimellisen vietin inhimillistämisen muodosta, joka jalosti vietin ja raa'an voiman rakkauden palvelukseen. Sukupuolielämä oli siis avioliiton perusta, ja avioelämä määrittyi oleellisesti seksuaaliseksi elämäksi. Ruumiin luonnollisia seksuaalisia toimintoja ei pitänyt enää estää, vaan niiden tuli "antaa toteutua" hallitusti. Normaalia oli nyt samanaikainen hekuman huippu ja orgasmi, joka oli sekä objektiivisesti ärsykekynnyksinä ja laukeamisreaktioina havaittava empiirinen tosiasia että subjektiivisesti tyydytyksen kautta koettu elämys. Miehen yhteiskunnalliseksi vastuuksi asettui rakastamisen taidon hallinta, jonka puutteesta kertoivat naisen patologiset piirteet (kuten partakarvojen kasvu). Kyse ei kuitenkaan ollut itämaisen ars erotican tulosta läntiseen kulttuuriin vaan tekniikasta, jolla pystyttäisiin toteuttamaan tyydytetyn naisen normi. Tämä taito oli sukupuolitettu ja antoi vielä päävastuun tämän tärkeän yhteiskunnallisen tehtävän suorittamisesta miehelle. Voitaisiin sanoa, ettei hyvä perheenisä voinut olla enää vanha despotos, absoluuttinen kodin herra, joka otti naisensa niin kuin huvitti, vaan tuottavan ja onnellisen kodin luomiseksi hänen oli huolehdittava kodin nautintotaloudesta, naisen orgasmista. Sitä paitsi avio-onnen ja terveen äidin palvelemisen nähtiin tuottavan miehelle myös eettistä tyydytystä. Miehen oli siis opittava tuntemaan naisen monimuotoinen seksuaalisuus, osattava herättää naisensa halu ja johdattaa tämä hekumansa huipulle. Naisen taas oli aktiivisen pasiiivisesti heittäydyttävä rakastajantaitoisen miehensä vietäväksi. Mutta jos miehen, joka oli myöskin sukupuoliolento, orgasmi oli lähinnä mekaanisen hankauksen tulos, niin nainen, joka oli ainoastaan sukupuoliolento, edusti sukupuolisuutta kokonaisvaltaisesti ja oli monimutkaisemmin seksuaalinen. Ongelmana ei ollut vain miehen helppo epäonnistuminen vaikessa tehtävässä vaan myös se, ettei tämä aina osannut tunnistaa naisen mysteerisen orgasmin merkkejä tai paljastaa mahdollista "patologista" teeskentelyä. Siksi tiede oli tuotava miehen avuksi ja onneksi gynekologia, anatomia ja fysiologia tuottivat auttavan koodiston ja kartaston naisen käsittämättömän ruumiin lukemiseen ja mahdollisuuden kunnialliseen selviytymiseen sen kàsittelystä. Tämä tarkoitti naisruumiin intensifioimista; siitä oli tunnettava erogeeniset vyöhykkeet, nesteiden, hormonien, hermoston ja psyyken vaikutus, jotta mies ohjailijana voisi herättää nauttivan naisen oman seksuaalisuutensa kokemuksen subjektina.

Nainen oli tietenkin myös 
seksuaalisissa häiriöissä monimutkaisempi, ja siinä missä impotenssi ja ennenaikainen siemensyöksy käsitettiin yksinkertaisina ruumiin toimintahäiriöinä, oli naisen yleisin seksuaalisen epänormaaliuden muoto, kylmyys, frigiditeetti, paljon monimutkaisempi asia. Frigidistä naisesta nousi samanlainen kulttuurinen hahmo kuin hysteerinen nainen oli ollut vuosisadan alussa. "Kuumuuden" sijaan ongelma oli nyt luonnonvastainen "kylmyys". Se oli kyvyttömyyttä tuntea nautintoa, jonka luonto alunperin oli antanut houkutellakseen ihmiset täyttämään sukupuolisen velvollisuutensa. Kylmä nainen ei uhannut vain avioliiton tuotannollista, reproduktiivista tehtävää vaan rikkoi myös sen aseman onnellisuuden ja turvallisuuden tuojana. Frigiditeetissä naisen normaalit potentiaalisuudet eivät päässeet aktualisoitumaan, ja naimaton nainen ei ollut enää enkelten sukua vaan patologinen tapaus, jonka karmaisevina vaihtoehtoina oli jäädä neitsyeksi, siis tukahduttaa halu (patologista) tai sitten vääristää se (patologista) nymfomanian tai lesbouden suuntaan.

"Pariutumisen etiikassa" yksilöllinen elämänhallinta yhtyikin yhteiskunnalliseen elämänhallintaan. Henkilökohtaisesta tuli poliittista ja yhteiskunnallisen järjestyksen kriittinen piste. Seksuaalivallankumous ja feministinen kritiikki luhisti tosin ydinperheen pariutumisen ongelman ja julisti sen naisellisuuden stereotypiat mystiikaksi, mutta säilytti suureksi osaksi vanhan kielen. Orgasmin ongelma määritti edelleen 60- ja 70-lu- vun oppaissa omaa seksuaalisuutta. Helénin lopetus onkin analoginen Foucault'n $L a$ volonté de savoir -teoksen lopetukseen: "Dispositiivin ironia: se sai meidät uskomaan että kyseessä oli oma "vapautumisemme." Artikkeli onkin erinomainen analyysi pariutumisen etiikasta, vaikka välillä tutkijan halu alkaa ehkä kiertää hieman ympyrää niissä diskursiivisissa, poliittisissa ja rakenteellisissa tekijöissä, joilla valta diagnosoi naista. Vaarana on, että naista objektivoiva vallan katse muodostuu itseään tukevaksi tautologiaksi, jolloin ollaan helposti takaisin puhtaassa alistus-hypoteesissa, jota "foucault'lainen" tutkija varmasti haluaa välttää. Tosin on ymmärrettävää, mihin vaaraan naisen ruumiista kirjoittava mies joutuu, jos ei muista korostaa sen ainaista kontrollia.

Orgasmin ongelmista oppineina voimme todeta, että onneksi meillä on aviomiehen rakastajantaitojen tyydyttämä naispoliitikko, jonka seksuaalisuus on aviollista, normaalia ja tervettä ja joka osaa heittäytyä miehensä vietäväksi yhtenä revänä ilman frigiditeetin patologioita. Ajatelkaa nyt tuossa asemassa tyydyttämätöntä vanhaapiikaa, joka voisi purkaa seksuaalisia patologioitaan poliittisella kentällä. Tai sitten homoseksuaalia, joka Achtén Psykiatrian valossa on myös patologinen tapaus, tai kuten Stålström lainaa Achtén toista artikkelia: "Yhtä hyvin kuin epilepsiaa sairastava ei sovi autonkuljettaksi, ei homoseksuaalinen henkilö sovi nuorisotyöntekijäksi."

Tämän typeryyden Olli Stålström nostaa esiin homo- seksuaalisuuden sairausleimauksia ja kontrollointia käsittelevässä kirjan päättävässä artikkelissa. Juutalais-kristillinen traditio näyttäytyy jälleen päävihollisena ja kyllä hieman virheellisesti lähes kaiken homoseksuaalisuuden tuomitsemisen lähteenä. (Esimerkiksi Stålströmin kritisoima ajatus luonnon tarkoituksista ei todellakaan ole kristillistä perua. Itse asiassa juuri kristillinen pelastuksellinen historiankäsitys erotti ajan tähtien luonnollisesta liikkeestä ja inhimillisen ajan luonnon tarkoituksista.) Kristinusko painotti myös puhtaasta suvunjatkamisesta erillistä rakkauden ideaa ja loi munkkiveljeskuntien kautta tietyn mahdollisen alueen aviosta kieltäytyvien miesten oman rakkauden yhteisön luomiselle.

Keskeistä moderneille homoseksuaalien sairasluokituksille on kuitenkin näiden ero sekä antiikin kritiikistä (siementen luonnoton tuhlaus) ja kristillisestä moralismista (synnillinen teko) ja erityinen moderni "biologis-psykologis-rasistinen" diskurssi, joka keskittyi juuri kielletyn teon tuomitsemisen sijasta fysiologisen tyypin olemuksen etsimiseen, joka sitten määrää koko ihmisen psyko-fyysillistä persoonallisuutta. Stålström käsitteleekin tätä ja mainitsee myös kuinka itse asiassa homoseksuaalisuuden puolustajat olivat niitä, jotka innokkaimmin tarjosivat 1800-luvulla mallia homoseksuaalisesta tyypistä. (Tähän ongelmatiikkaan liittyvät tietenkin Foucault'n kirjoitukset siirtymisestä teosta tyyppiin ja vallan kiinnittymisestä ihmiseen psykofyysisenä kokonaisuutena, mutta mielenkiintoisia keloja 
tästả kokonaisvaltaisesta identiteetistä ja sen poliittisesta merkityksestä julkisen ja yksityisen alueen muuttuvaan rooliin sekä modernin rasismin syntyyn liittyen esittää myös Hannah Arendt esimerkiksi teoksessaan The Origins of Totalitarism.) Viitaten Helénin artikkeliin homoseksuaali tulee modernissa diskurssissa määritellyksi naisen tavoin täysin sukupuolisuuden määräämänä tyyppinä, mutta poikkeavan sukupuolisuuden ilmentymänä heteroseksuaalisuuden asettuessa (ei suinkaan raamatullisena käskynä vaan) biologisena normina. Orgasmin keskeisyys asetetaan täällä siittämisen ratkaisevana pisteenä. Normaalius ei kuitenkaan sulje perversiota ulkopuolelleen (kuten Stålström kirjoittaa), vaan normaalius (abstraktio) määrittyy pikemminkin juuri havaitun perversion (konkreettinen) kautta ja homoseksuaalisuus kuuluu normaalin alueeseen, tosin tietenkin sen epänormaalina tyyppinä. Tässä onkin tärkeää Stålströmin nostama kritiikki homoseksuaalisuutta häiriönä pitävää tutkimusta kohtaan sen keskittymisestä pelkkiin potilasotoksiin, jossa tautologisesti häiriöinä nähdảản ne, jotka ovat jo itse ahdistuksen takia ajatuneet hoitoon ilman vertailuryhmää muista homoseksuaaleista. Mutta tässäkin kyse on juuri abstraktiosta; normaalia ei ole, koska kyse on vain häiriöiden tutkimisen kautta luodusta abstraktiosta.

Tärkeistä huomioistaan huolimatta Stålströmin esitystä vaivaa hieman niin sanottujen "marginaalidiskurssien" historialle (naiset, lapset, mustat ja kaikki valtavirrassa alistetut) usein ominainen yksi- totisuus ja teorioiden niputtaminen kriteerillä, hyvảksyivätkö ne homot vai eivätkö hyväksyneet. On tietenkin mukavaa, että nykyään niin parjattu Freud saa myös positiivisia pisteitä, mutta mielenkiintoista olisi miettiä psykoanalyysin radikaaleja piirteitä tietoisuuden kyseenalaistajana, ulkoisuuden avaajana ja modernin biologismin ja toisaalta psykologisoivan normalisaation vastavoimana, eli kuten Stålström lainaakin Freudia: "Psykoanalyyttinen tutkimus vastustaa mitä päättäväisimmin kaikkia yrityksiä erottaa homoseksuaalit muusta ihmiskunnasta ryhmäksi, jolla on tietyt ominaisuudet." Tätä voisi verrata toisaalta psykoanalyysin asemaan (varsinkin amerikkalaisessa egopsykologiassa) modernin terapeuttisen sopeuttamisen välineenä. Stålstromin "hyvän, homoja ymmärtävän Freudin" ja "pahan, homoja vainoavan adaptiopsykologian" esittävässä taulukossa adaptionistisen näkemyksen nähdään kiistävän ihmisen perimmäinen biseksuaalisuus, mutta eikö ole yhtä älytöntä tehdä biseksuaalisuudesta ihmisen perimmäistä ominaisuutta kuin heteroseksuaalisuudesta. (Näemmekö päivän jolloin ihmisiä kastroidaan, koska nämä eivät ole toteuttaneet perimmäistä biseksuaalisuuttaan?) Stålström kritisoi adaptiopsykologeja myös uusimman tutkimuksen sivuuttamisesta, mutta jos leikillisesti sanottaisiin, että entäpä jos "tieteen viimeinen sana" löytäisikin homoseksuaalisuuden kanssa korreloivan geeniyhdistelmän, johon "sokea kellośeppä" olisi raapustanut koodin "olen elämän normaalin kulun vastainen". Olisiko tảmä syy homosikiöiden selektointiin pois? Poliittisesti homoseksuaalien kontrollin korostaminen on toki tärkeää, mutta ongelmaa tarkemmin käsittelevässä artikkelissa voisi olla myös hieman monisyisempää pohdintaa.

\section{ORGAANIEN ÄÄNESTÄ}

Kaikista "pikkunäppäristä" kommenteistani huolimatta Terveyden läbteillä on mielenkiintoista luettavaa, varsinkin maailmassamme, jossa terveys asetetaan yhdeksi ylimmistä arvoista niin yksilöllisessä kokemuksessa kuin yhteiskunnan organisoimisessakin ja jossa myös syntyy sellaisia omituisia juridisia käsitteitä kuin oikeus terveyteen. Tätä oikeutta ei tietenkään yksikään maanpäällinen suvereeni voi kuolevaiselle ihmiselle taata ja sen vaade on loppumaton, ainakin niin kauan kun säilytämme länsimaista terveyden ontologiaa hallinneen ajatuksen "orgaanien hiljaisuudesta" terveyden merkkinä. Kenties meidän olisi opittava elämään myös sairauden kanssa (eikä tämä ole uusliberalistinen argumentti terveyshuollon vähentämisen puolesta ja ihmisten hoidotta jättämisen juhlintaa) tai kehittämään käsityksiä kolmannesta tilasta, neutrumista, toipumisena orgaanien hiljaisuuden perinnöstä. Hiljentykäämme siis lopuksi, me terveyden palvojat, kuuntelemaan tieteenfilosofin ja yhden "kolmannen tilan" etsijöistä, Michel Serresin, sanaa: "Sinä pelkäät ahdistustasi, joten kiiruhdat vaihtamaan. sen johonkin rahasummaan, sillä tavalla ahdistustasi voidaan mitata ja vertailla vaihdon ylei- 
sen standardin mukaan. Sinä pelkäät ääntä, sitä ääntä, joka nousee orgaanien hiljaisuudesta. Se kiertää, kirkuu, riuhtoo mielenvikaisuuteen asti. 'Hiljennä ääni!' - sillä terveys, näin he sanovat, on ainoastaan orgaanien hiljaisuutta. Ei, sillä sovittamaton, levottomuus ja kohina, joka kulkee sanattoman ruumiin kautta, ovat usein elämämme ohjenuoria. Tappaa tämä loismainen häiriö, tukahduttaa alkava meteli, pelätä omia kyyneleitä - eikö tämä ole sama virhe kuin poistaa hajaannus kirkkaasta ajattelusta?"”

Markku Koivusalo

\section{$v i j t$ te t}

1. Ks. Foucault'n johdanto teokseen Cangulhem: The Normal and the Patbological

2 Vlastos, Gregory: "Solonian Justice". Classical Philology XII, 1946, s. 65

3. Hippokrates. "Pyhasta Taudista" Suomen Lääketieteen Historian Seuran vuosikirja 1986, s. 25 .

4. Tasta mm. Capizzi Antonio: The Cosmic Republic. J. C. Gieben 1990

5 Tasta kinnostuneille entyisest1 Agamben, Giorgio. Stanzas Word and Phantasm in Western Culture. 1993.

6. Kaannos Kaisa Sivenuus. Foucault'n Tiedontabto ilmestyy Gaudeamukselta.

7. Serres, Michel. The Parasite. The John Hopkins University Press 1982, s. 235.

\section{DANZAHAVI: Husserl und die transzendentale Intersubjek- tivität, Eine Antwort auf die sprachpragmatische Kritik. Phenomenologica 135, Klu- wer Academic Publishers, Dordrecht 1996.}

Tämän vuosisadan filosofian painottumista kieleen on perusteltu subjektivismin ja solipsismin välttämisellä. Lähtemällä liikkeelle kielestä filosofia on näin onnistunut aloittamaan intersubjektiiviselta alueelta ja välttämään monet kartesiolaisuudesta periytyvät ongelmat. Vaikka juuri näiden ongelmien selvittäminen oli keskeinen osa Edmund Husserlin elämäntyötä, hänen fenomenologiansa on kuitenkin usein yhdistetty solipsismiin. Nyt tilanne on vähitellen muuttumassa.

Husserlin fenomenologian sosiologisuus on tullut tutkijayhteisön tietoisuuteen hitaasti. Osittain tilanne johtuu tekstien huonosta saatavuudesta. Viides karteesinen mietiskely, Husserlin ensimmäinen julkaistu tutkimus intersubjektiivisuudesta, ilmestyi saksaksi vasta vuonna 1950 Husserlianan ensimmäisenä niteenä. Tämä pieni tutkimus oli seuraavat 20 vuotta laajin osoitus arkkifenomenologin 30 vuoden jatkuvista ponnisteluista muiden subjektien ongelman kanssa. Vuonna 1973 Husserlianassa julkaistiin sitten postuumeista papereista kasatut intersubjektiivisuusniteet (Husserliana 13-15). Teosten ilmestyttyä ensimmäisen Husserlianan toimittanut Stephan Strasser kirjoitti niteistä seuraavasti: "Jos haluaa vakuuttua Husserlin ajattelun rikkaudesta on on hyvä nähdä se vaiva, että käy läpi ne kolme nidettä, jotka tuovat esiin Husserlin intersubjektiviteetin fenomenologian kehitysvaiheis- saan. "Läpikäynti ei kuitenkaan käy ihan yhdeltä istumalta, sillä niteet käsittävät lähes 2000 sivua ja koostuvat 91 tutkimuksesta joihin on yhdistetty lähes 200 liitettä. Seuraavat 20 vuotta tutkijayhteisöltä on sitten mennyt tämän materiaalin sulattamiseen.

Nyt, kun Husserlin ensimmäisistä yrityksistä selvittää muiden subjektien ongelmaa on kulunut jo yli 90 vuotta, kuva näyttää vihdoin olevan kirkastumassa. Samalla on käynyt ilmeiseksi, että käsitys intersubjektiivisuudesta on olemuksellinen osa Husserlin fenomenologiaa. Tuoreessa väitöskirjassaan Husserl und die transzendentale Intersubjektivität Dan Zahavi väittääkin, että husserlilainen transsendentaalifilosofia eroaa olennaisesti kantilaisesta juuri koska se on alusta alkaen intersubjektiivista. Intersubjektiivisuus ei ole täydennys Husserlin tarkasteluihin vaan pikemminkin niiden keskeinen peruspilari.

Kaksi kolmasosaa teoksesta muodostuu Husserlin transsendentaalin intersubjektiivisuusteorian tulkinnasta. Zahavi painottaa aluksi fenomenologin suhdetta maailmaan. Tarkastelu ei ala maailmasta irrottautumisella eikä maailmassa olevien mielen erotuksella niiden olemisesta. Näin Zahavi asettuu vastustamaan suurta osaa perinteisestä Husserl-tulkinnasta, jossa mielen erottaminen olemisesta tuottaa tutkittavat puhtaat ilmiöt. Zahavin Husserl sen sijaan kirjoittaa: "Maailmaa ei menetetä epokhéssa, joka ei ylipäänsä tarkoita pidättäytymistä suhteessa maailman olemiseen ja sitä koskevista väitteistä“ (s. 7; Hu15, s. 366). Husserlin transsendentaalifilosofinen lähtökohta ymmärretään 